\title{
Comparison of Mother Tongue Teaching Curriculums Implemented at the Middle School Level in Turkey and England
}

\author{
Nigar Ipek Egilmez \\ Turkish Language Arts, Muğla Sitkı Koçman University, Turkey
}

Copyright $(2018$ by authors, all rights reserved. Authors agree that this article remains permanently open access under the terms of the Creative Commons Attribution License 4.0 International License

\begin{abstract}
The current study aims to reveal the similarities and differences by comparing the mother tongue teaching curriculums implemented at the middle school level in Turkey and England in terms of "their structure, objectives, learning areas and learning outcomes". The current study employed the survey model used to reveal the subject of interest as it is and the collected data were analyzed through the document analysis method. In the current study, "The Turkish Teaching Curriculum" revised in 2018 and "The National Curriculum in England-English: Key Stage: 3", which is the mother tongue teaching curriculum of England, were compared. "English: Key Stage: 3" was developed to teach their mother tongue to students aged 11-14 and corresponds to 6th, 7th and 8th grades of The Turkish Teaching Curriculum". First the mother tongue teaching curriculums of Turkey and England were downloaded from the official websites. The curriculums were analyzed in a detailed manner in terms of "structure, objectives, learning areas and learning outcomes" to reveal similarities and differences.
\end{abstract}

Keywords Mother Tongue Teaching Curriculum, Turkish Education, Turkish Teaching Curriculum, The National Curriculum in England, English, Key Stage 3

\section{Introduction}

Language is a human-specific ability enabling communication between people. Language is a multi-faceted and developed system that allows thoughts, feelings and desires to be communicated to others by making use of words and rules common to a society in terms of sound and meaning [1]. From a communication point of view, language is one of the most basic needs for people to live together. Language creates a link between people, as well as a bridge between the past and the future.

While a person has the skills of listening and speaking until he/she starts the school, he/she acquires language skills in reading and writing with the beginning of their formal education at school. In today's information age, the importance of using these language skills effectively, communicating well with other people and reading and questioning information from different sources is indisputable.

Students' developing their listening and speaking skills that they have already acquired before coming to school and their being effective readers and writers depend on an effective mother tongue teaching given at schools. Mother tongue is the language that is heard by the child from his/her mother, family and people in the close circle and helps the child perceive the world and shape his/her frame of mind. According to Aksan [2] "Mother tongue is the language that is first learned from the mother and family and then from the people he/she interacts with in the close vicinity, that penetrates into the sub-conscious mind and establishes the individual's strongest connections with the society."

Mother tongue education should be offered with the start of elementary education for the individual to develop his/her language skills and to enable the mother language to be used in a correct, fluent and effective way. According to Sever [3], "Mother tongue education is a process starting with elementary education and affecting the success in all courses. In this process, it is aimed to develop students' comprehension and expression skills."

For an effective mother tongue education, the educational and instructional process should be planned well. In other words, there is a need for a good curriculum for an effective education. Varış [4] stresses that the general function of educational institutions is to enable students to adapt to the changing world and age by introducing them to the culture. "Schools working for children to adapt to the society in which they are living 
accomplish this task through education and to do so, they need to conduct these educational processes in an organized manner." [4].

One of the ways to be pursued while developing curriculums is examining the curriculums of different countries. The comparative education, which deals with the comparison of curriculums in different countries, is a research field identifying and interpreting the current problems in societies and the underlying causes of these problems by considering similar elements in other societies [5].

The comparative education is a discipline aiming to help to identify similarities and differences between the education systems in different countries, to explain similar phenomena and to make useful proposals about how to deal with education on the one hand and a research field investigating different policies about education, regulations concerning education and financial resources of education on the other hand [6].

Only through a good language education, it will be possible to train individuals who are able to express themselves, understand the outside world, live in harmony with the society they live in and have high academic success. The efficiency of Turkish teaching is influenced by many sources such as curriculum, textbook, teacher, student and parent. One of these elements, the curriculum of the Turkish course is a guide which indicates the objectives that the student should attain. In terms of language and communication skills, the curriculum aims to train individuals who can understand what they are listening and reading and who can express their feelings and thoughts verbally and in writing. The quality of the curriculum can directly affect the quality of the student. For this reason, the Turkish teaching curriculum should be continuously developed and renewed and shaped according to the goals of the country and the requirements of the age. To this end, the current study aimed to explore the mother tongue teaching curriculum implemented in England as English is the language preferred by people speaking different languages as a means of communication and as it is the language most studied as a foreign language in many countries. Thus, it was aimed to compare the mother tongue teaching curriculum implemented in England and Turkish teaching curriculum in terms of the elements of mother tongue education. In this way, it is believed that some suggestions can be made for the positive features of the mother tongue teaching curriculum implemented in England to contribute to the development of the Turkish teaching curriculum. Investigation of curriculums of different countries is important to gain new perspectives. The main purpose of the current study is to compare the Turkish teaching curriculum implemented at the middle school level in Turkey and the national mother tongue teaching program implemented at the middle school level in England in terms of teaching of mother tongue.

\section{Materials and Methods}

\subsection{Research Design}

The current study aiming to compare the mother tongue teaching curriculums implemented at the middle school level in Turkey and England in terms of structure, general objectives, learning areas and learning outcomes is a descriptive study employing the survey model used to reveal an existing state as it is. In the survey model, "the event, individual or object that is the subject of the research is attempted to be defined as it is in its own conditions" [7]. In the current study, it was aimed to reveal the similarities and differences between the curriculums of the two countries by using qualitative research methods. Qualitative research refers to "a type of research in which a qualitative process is followed to reveal perceptions and incidences in their natural environment in a realistic and integrative manner by using qualitative data collection tools such as observations, interviews and document analysis" [8].

\subsection{Data Collection and Investigated Documents}

In the current study, the Turkish teaching curriculum developed by the Ministry of national education (Elementary and middle school 1st, 2nd, 3rd, 4th, 5th, 6th, 7th and 8th grades) [9] and The National Curriculum in England: Key Stages 3 and 4 Framework Document [10] implemented at the middle school level in England were examined. The mother tongue teaching curriculums of the both countries were downloaded from their official websites.

While the learning outcomes in the National Curriculum in England are presented as a whole for the middle school level, the learning outcomes of the Turkish Teaching Curriculum are given separately for each grade level from 1 st grade to the 8 th grade. Thus, it was not possible to compare the curriculums of the two countries on the basis of grade level; therefore, a general comparison was made for the middle school level.

Table 1. Examined Mother Tongue Teaching Curriculums

\begin{tabular}{|c|c|c|c|c|}
\hline Country & Examined Curriculum & Year of Issue & $\begin{array}{c}\text { The Number of } \\
\text { Pages }\end{array}$ & $\begin{array}{c}\text { The Number of } \\
\text { Learning Outcomes }\end{array}$ \\
\hline Turkey & Turkish Teaching Curriculum & 2018 & 66 & 84 \\
\hline England & $\begin{array}{c}\text { The National Curriculum in England: Key Stages 3 and } \\
\text { 4 Framework Document }\end{array}$ & 2014 & 105 & 30 \\
\hline
\end{tabular}


There are a total of 220 learning outcomes stated in the Turkish Teaching Curriculum for 6th, 7th and 8th grades. Due to the circular structure of the curriculum, many learning outcomes are addressed in three of the grade levels. In order to be able to find only the different learning outcomes, all the learning outcomes were collected in a pool, then the same learning outcomes were combined and thus a total of 84 learning outcomes were obtained.

While determining the parts of the curriculums to be compared, the age groups and grade levels they are for were also taken into consideration. In our country, though 5 th grade is within the middle school education, in England it is in the "Key Stage 2" age group of the English National Curriculum; thus, it was excluded from the comparison and as a result, only 6 th, 7 th and 8 th grades were compared.

\subsection{Analysis of the Data}

The current study employed the "document analysis method" one of the qualitative research methods. "The document analysis involves the analysis of the written materials including information about the phenomenon or phenomena to be researched." [8]. In this respect, the mother tongue teaching curriculums implemented at the middle school level in Turkey and England were examined, compared and their similarities and differences were elicited. The obtained data are presented with excerpts from the programs and in tables.

\section{Findings}

The mother tongue teaching curriculums implemented at the middle school level in Turkey and England were examined, the obtained data were evaluated under four main headings "structure, objectives, learning areas and learning outcomes" and the results were comparatively presented.

\subsection{Comparison of the National Curriculum in England-English: Key Stage: 3 and Turkish Teaching Curriculum in terms of "Structure"}

Compulsory education in England starts from the age of 5 and continues until the age of 16 . This 12 year process is divided into four periods and separate curriculums are prepared for each period. In the following table, these periods and their age groups are presented.

Table 2. The Structure of the National Curriculum in England: Periods and Age Groups [10]

\begin{tabular}{|c|c|c|c|c|}
\hline & $\begin{array}{c}\text { Key Stage } \\
1 \\
\left(1^{\text {st }} \text { Period }\right)\end{array}$ & $\begin{array}{c}\text { Key Stage } \\
2 \\
\left(2^{\text {nd }} \text { Period }\right)\end{array}$ & $\begin{array}{c}\text { Key Stage } \\
3 \\
\left(3^{\text {rd }} \text { Period }\right)\end{array}$ & $\begin{array}{c}\text { Key Stage } \\
4 \\
\left(4^{\text {th }} \text { Period }\right)\end{array}$ \\
\hline $\begin{array}{c}\text { Age } \\
\text { Group }\end{array}$ & $5-7$ & $7-11$ & $11-14$ & $14-16$ \\
\hline Years & $1-2$ & $3-6$ & $7-9$ & $10-11$ \\
\hline
\end{tabular}

As can be seen in Table 1, the 3rd period (Key Stage 3) is for 11-14 year olds attending 7th, 8th and 9th grades. With the circular issued by the Ministry of National Education regarding compulsory education in Turkey, 8-year compulsory education was extended to 12 years [11]. In the same circular, it is also stated that "Compulsory education covers 4-year elementary education, 4-year middle school education and 4-year high school education. The first four-year period (1st, 2nd, 3rd and 4th grades) is called elementary education, the second four-year period (5th, 6th, 7th, 8th grades) is called middle school education and the third four-year period (9th, 10th, 11th, 12th grades) is called high school education." [11] While the compulsory education in Turkey is divided into three periods, it is divided into four periods in England. The third period of the English National Curriculum (key stage 3) corresponds to the period covering 6th, 7th and 8th grades in Turkey in terms of both age groups and grade levels.

Table 3. The Content of the Turkish Teaching Curriculum

\begin{tabular}{|c|c|}
\hline Turk & Teaching Curriculum $\left(1^{\text {st }}-8^{\text {th }}\right.$ Grades $)$ \\
\hline The I & istry of National Education Curriculums \\
\hline Obje & es of the Curriculums \\
\hline $\begin{array}{c}\text { Persp } \\
\qquad \\
\cdot \\
\bullet\end{array}$ & $\begin{array}{l}\text { ve of the Curriculums } \\
\text { Values } \\
\text { Competences }\end{array}$ \\
\hline Meas & ment and Evaluation Approach in the Curriculums \\
\hline Perso & Development and Curriculums \\
\hline Resul & \\
\hline Appli & ion of the Turkish teaching curriculum \\
\hline 1. & Special objectives of Turkish teaching curriculum \\
\hline 2. & Learning teaching approach \\
\hline 3. & Measurement and evaluation approach \\
\hline 4. & Points to be considered in the application \\
\hline $\begin{array}{l}\text { The } \mathrm{r} \\
1^{\text {st }}-8^{\text {th }}\end{array}$ & $\begin{array}{l}\text { ber and size of the textbooks used in Turkish courses for } \\
\text { ides }\end{array}$ \\
\hline & ture of the Turkish teaching curriculum \\
\hline 1. & The structure of the curriculum \\
\hline 2. & The structure of the learning outcomes \\
\hline 3. & Learning outcomes and explanations \\
\hline $\begin{array}{l}\text { Learn } \\
\text { curric }\end{array}$ & $\begin{array}{l}\text { outcomes and explanations table for the Turkish teaching } \\
\mathrm{m}\end{array}$ \\
\hline
\end{tabular}

In the curriculum, first the general features of the curriculums prepared by the Ministry of National Education are described and then the objectives of the curriculums are discussed. Under the title of the perspective of the curriculums, there are the sections "values" and "competences" included in the curriculum for the first time. Then come the sections "Measurement and Evaluation Approach in the Curriculums", "Personal Development and Curriculums" and "Result". The content of these first six headings addressed up to now is found in the curriculums of all the courses published in the official website of the Ministry of National Education. The 
following sections of the curriculums are specially designed for each course.

The explanations directly targeting the course in the Turkish teaching curriculum start with the section "Application of the Turkish Teaching Curriculum". Then it is followed by the sections "Special Objectives of the Turkish Teaching Curriculum", "Learning Teaching Approach", "Measurement and Evaluation Approach", "Points to be considered in Application". Following the section "The number of textbooks and their sizes used in Turkish courses of 1st-8th grades" describing the formal features of the textbooks, grade level-specific learning outcomes and their explanations are given. The learning outcomes are given separately for each grade level from 1 st grade to 8 th grade.

Table 4. The Content of the National Curriculum in England

\begin{tabular}{|c|c|}
\hline \multicolumn{2}{|r|}{ The National Curriculum in England } \\
\hline \multicolumn{2}{|c|}{ Introduction } \\
\hline \multicolumn{2}{|c|}{ Curriculum in England } \\
\hline $\begin{array}{r}\text { Nati } \\
\bullet \\
\bullet\end{array}$ & $\begin{array}{l}\text { Curriculum in England } \\
\text { Objectives } \\
\text { Structure }\end{array}$ \\
\hline Incl & $\begin{array}{l}\text { Development of the Appropriate Expectations } \\
\text { Meeting Students' Needs and Overcoming Potential } \\
\text { Obstacles for Individual Students and Student Groups }\end{array}$ \\
\hline \multicolumn{2}{|c|}{ Number and Mathematics } \\
\hline Lan & $\begin{array}{l}\text { e and Literacy } \\
\text { Speaking } \\
\text { Reading and Writing } \\
\text { Vocabulary Development }\end{array}$ \\
\hline Eng & $\begin{array}{l}\text { Purpose of studying } \\
\text { Objectives } \\
\text { Spoken Language } \\
\text { Reading and Writing } \\
\text { Dictionary }\end{array}$ \\
\hline Key & $\begin{array}{l}\text { 3: Course Content } \\
\text { Reading } \\
\text { Writing } \\
\text { Grammar and Vocabulary } \\
\text { Spoken Language }\end{array}$ \\
\hline Key & $\begin{array}{l}\text { ge Course Content } \\
\text { Reading } \\
\text { Writing } \\
\text { Grammar and Vocabulary } \\
\text { Spoken Language }\end{array}$ \\
\hline \multicolumn{2}{|c|}{ Dictionary } \\
\hline $\begin{array}{l}\text { Oth } \\
\text { Citi } \\
\text { Hist }\end{array}$ & $\begin{array}{l}\text { urses (Mathematics, Science, Painting and Designing, } \\
\text { ip, Programming, Design and Technology, Geography, } \\
\text { anguage, Music, Physical Education }\end{array}$ \\
\hline
\end{tabular}

The Turkish teaching curriculum was prepared on the basis of the thematic approach in such a way as to allow making sense of what has been read through intra-textual, non-textual and inter-textual reading. In the curriculum, from 1st grade to 8th grade, all the learning outcomes related to language skills, higher order cognitive skills, grammar and spelling rules are structured in a gradual manner with increasing intensity in line with the developmental characteristics of students [9].

In England, compulsory education is divided into four periods (key stages). The 3rd period (key stage 3) is designed on the basis of twelve courses and the courses are classified as core subjects and foundation subjects. The National Curriculum in England-English: Key Stage: 3 starts with an "introduction" briefly explaining the content of the curriculum and then continues with a section explaining the school and national curriculums in England.

There are two different curriculums in England which are "school curriculum" and "national curriculum". The national curriculum is the core curriculum that must be followed by all the state, foundation, private etc. schools across the country. The national program presenting an outline of the general framework primarily "provides pupils with an introduction to the essential knowledge that they need to be educated citizens. It introduces pupils to the best that has been thought and said; and helps engender an appreciation of human creativity and achievement." [10]. While the national curriculum presents the main points related to objectives to be accomplished by students, it leaves the details to schools. This is explained as follows in the curriculum, "The national curriculum provides an outline of core knowledge around which teachers can develop exciting and stimulating lessons to promote the development of pupils' knowledge, understanding and skills as part of the wider school curriculum." [10].

"Pupils of compulsory school age in community and foundation schools, including community special schools and foundation special schools, and in voluntary aided and voluntary controlled schools, must follow the national curriculum. It is organised on the basis of four key stages and twelve subjects, classified in legal terms as 'core' and 'other foundation' subjects. The Secretary of State for Education is required to publish programmes of study for each national curriculum subject, setting out the 'matters, skills and processes' to be taught at each key stage. Schools are free to choose how they organise their school day, as long as the content of the national curriculum programmes of study is taught to all pupils." [10].

In England, each school has a special school curriculum that comprises all learning and other experiences that it plans for its pupils. "The national curriculum forms one part of the school curriculum... Maintained schools in England are legally required to follow the statutory national curriculum which sets out in programmes of study, on the basis of key stages, subject content for those subjects that should be taught to all pupils." [10]. In addition to this, while all schools have to publish online their special curriculums indicating the courses and the academic year, they have the freedom of planning their own curriculums and including courses and subjects they want in their 
curriculums. Moreover, in their school curriculums, it is stated that all the state schools "are required to make provision for a daily act of collective worship and must teach religious education to pupils at every key stage and sex and relationship education to pupils in secondary education." [10].

This structure provides a wide range of freedom for schools in England. Schools can add new course contents to the course contents defined in the national curriculum; can shape the instructional period; can choose the course materials they will use and can add new courses to the curriculum when needed. The Turkish Teaching Curriculum implemented in our country was developed to be applied in all the state and private schools throughout the country. The learning outcomes to be accomplished by students for each grade level are explained in detail. Thus, no matter where the teacher works, he/she has to follow this curriculum developed by the Ministry of National Education.

When the curriculums of the two countries are structurally examined, it is seen that while the curriculums are divided into sections, key stages are taken into consideration in England, yet, in Turkey this division is done on the basis of grade level. In the official website of England, there are four different booklets for these four different periods and in each booklet, the contents of the courses for the related period are presented. In the official website of Turkey, there is a separate booklet for each course and in each course booklet; the contents of the course prepared for all the grade levels are presented.

Unlike the National Curriculum in England, in the Turkish Teaching Curriculum [9], the importance of all the values to be imparted to students is also explained. These values explained as the core values are "justice, friendship, honesty, self-control, patience, respect, love, responsibility, patriotism, benevolence". In addition, in the Turkish Teaching Curriculum [9], the competences to be imparted to students are also defined. These are: "communication in the mother tongue, communication in foreign languages, mathematical competence, and basic competences in scienceltechnology, digital competence, learning how to learn, social and citizenship-related competences, taking initiative and entrepreneurship, cultural awareness and expression".

\subsection{Comparison of the National Curriculum in England-English: Key Stage: 3 and the Turkish Teaching Curriculum in terms of "Objectives"}

The special objectives of the Turkish Teaching Curriculum were prepared on the basis of the General Objectives and Basic Principles of the Turkish National Education stated in the 1973 Basic Law of the National Education. In the curriculum, it is aimed;

- ' $\quad$ to develop students' listening/watching, speaking, reading and writing skills,
- to enable students to consciously, correctly and prudently use Turkish in compliance with the rules of spoken and written language,

- to enable students to gain the pleasure and consciousness of using language by enriching their vocabulary on the basis of what they have read, listened/watched and to enable them to foster their worlds of emotions, thoughts and imagination,

- to enable students to acquire the love and habit of reading,

- to enable students to effectively and comprehensibly express their feelings, opinions or theses about a subject by using spoken or written language,

- to develop students' skills needed to search, discover and interpret information and construct it in the mind,

- $\quad$ to develop students' skills needed to have access to information through printed materials and multi-media sources, to organize, question, use and produce it,

- to enable students to evaluate and question what they have read with a critical point of view,

- to encourage students to care about national, spiritual, historical, cultural and social values and to strengthen their national feelings and sensitivities,

- to make them recognize and adopt aesthetic and artistic values through the works belonging to the Turkish and world cultures and arts" [9].

As can be seen, the Turkish Teaching Curriculum aims to develop students' language and effective communication skills, to enrich their vocabulary, to help them gain the pleasure and consciousness of using the language, to develop their worlds of emotions, thoughts and imagination, to enable them to acquire the love and habit of reading, to develop their skills needed to have access to information, organize, question, interpret it and construct it in the mind, to enable students to gain a critical point of view, to nurture students' national, spiritual, ethical, historical, cultural and social values and to make them recognize aesthetic and artistic values through the works of national and international literatures.

In the National Curriculum in England, the general objective of the English course is explained as follows; "to promote high standards of language and literacy by equipping pupils with a strong command of the spoken and written word, and to develop their love of literature through widespread reading for enjoyment" [10]. In line with this general objective, the curriculum aims to enable students to;

- $\quad$ "read easily, fluently and with good understanding

- develop the habit of reading widely and often, for both pleasure and information 
- acquire a wide vocabulary, an understanding of grammar and knowledge of linguistic conventions for reading, writing and spoken language

- $\quad$ appreciate our rich and varied literary heritage

- $\quad$ write clearly, accurately and coherently, adapting their language and style in and for a range of contexts, purposes and audiences

- $\quad$ use discussion in order to learn; they should be able to elaborate and explain clearly their understanding and ideas

- be competent in the arts of speaking and listening, making formal presentations, demonstrating to others and participating in debate" [10].

The National Curriculum in England-English: Key Stage: 3 aims to equip students with a strong command of language and literacy skills, to develop their love of literature through a wide range of reading for pleasure, to improve their vocabulary, to enable them to learn the rules of grammar and use of the language, to make them appreciate their rich and varied literacy heritage, to enable them to select proper language and style for different contexts, goals and target populations and to enable them to discuss what they have learned and to make presentations.

The curriculum emphasizes that the mother tongue has a prominent place in education and society and that a quality English education will allow students to communicate their own ideas and emotions effectively. In the curriculum, it is pointed out that through reading in particular students can find a chance to develop "culturally, emotionally, intellectually, socially and spiritually". It is also stressed that all the language skills are needed for effective participation in the society; thus, "the students who cannot learn fluent speaking, reading and writing and cannot develop self-efficacy in using them are disenfranchised" [10].

When the two curriculums are compared in terms of their general objectives, it is seen that both of them emphasize the effective use of language skills, the development of vocabulary, teaching of grammar rules; yet, the National Curriculum in England-English: Key Stage: 3 brings speaking, discussion and presentation skills to the fore. In addition, the National Curriculum in England-English: Key Stage: 3 also aims to teach the importance of national literary works. The importance of these works is emphasized in the curriculum as follows [10]: "appreciate our rich and varied literary heritage". The curriculum defines the national literary works as heritage and describes this heritage as rich and varied and attempts to encourage students to appreciate this heritage; all these point to the importance attached to this issue. Another objective emphasized in the National Curriculum in England-English: Key Stage: 3 [10] is "develop the habit of reading widely and often, for both pleasure and information". This sentence indicates that rather than the acquisition of reading as a skill by students, the curriculum aims to encourage students to read for pleasure and to turn reading into a habit. As reading is the most important keystone in the mental, social, cultural etc. development of the individual, this objective is of great importance. Different from the National Curriculum in England, the Turkish Teaching Curriculum [9] aims to impart national, spiritual, cultural and social values to students and enable them to cognitively question, interpret and construct information.

\subsection{Comparison of the National Curriculum in England-English: Key Stage: 3 and the Turkish Teaching Curriculum in terms of "Learning Areas"}

The learning areas included in the mother tongue education curriculums implemented in Turkey and England are given in the following table.

Table 5. Learning Areas included in the National Curriculum in England-English: Key Stage: 3 and Turkish Teaching Curriculum

\begin{tabular}{|c|c|c|}
\hline \multirow{4}{*}{$\begin{array}{c}\text { The Learning } \\
\text { Areas in the } \\
\text { Curriculum }\end{array}$} & $\begin{array}{c}\text { Turkish } \\
\text { Teaching } \\
\text { Curriculum }\end{array}$ & $\begin{array}{c}\text { The National } \\
\text { Curriculum in } \\
\text { England-English: Key } \\
\text { Stage: } 3\end{array}$ \\
\cline { 2 - 3 } & Listening & - \\
\cline { 2 - 3 } & Speaking & Spoken Language \\
\cline { 2 - 3 } & Reading & Reading \\
\cline { 2 - 3 } & Writing & Writing \\
\cline { 2 - 3 } & - & Grammar and Vocabulary \\
\hline
\end{tabular}

In the National Curriculum in England-English: Key Stage: 3, there are four learning areas which are "spoken language", "reading", "writing", "grammar and vocabulary"; in the Turkish Teaching Curriculum, there are four learning areas which are "listening", "speaking", "reading" and "writing". In the National Curriculum in England-English: Key Stage: 3 "listening" and in the Turkish Teaching Curriculum, "grammar and vocabulary" are not addressed as a separate learning area. In the National Curriculum in England-English: Key Stage: 3, the learning outcomes related to listening are given within the learning areas of "writing" and "grammar and vocabulary"; in the Turkish Teaching Curriculum, the learning outcomes related to grammar and vocabulary are given within the other learning areas primarily within the learning area of "reading". In the National Curriculum in England-English: Key Stage: 3, there are short explanations for each learning area. These explanations are given below in detail.

\subsubsection{The "Spoken Language" Learning Area in the National Curriculum in England-English: Key Stage: 3}

In the spoken language learning area section of the National Curriculum in England, following explanations are made: "Pupils should be taught to speak clearly and convey ideas confidently using Standard English. They should learn to justify ideas with reasons; ask questions to 
check understanding; develop vocabulary and build knowledge; negotiate; evaluate and build on the ideas of others; and select the appropriate register for effective communication. They should be taught to give well-structured descriptions and explanations and develop their understanding through speculating, hypothesising and exploring ideas. This will enable them to clarify their thinking as well as organise their ideas for writing." Moreover, the national curriculum for English reflects the importance of spoken language in pupils' development across the whole curriculum-cognitively, socially and linguistically [10].

\subsubsection{The "Reading" Learning Area in the National} Curriculum in England-English: Key Stage: 3

In the explanation section concerning the "reading" learning area, it is stated that pupils should be taught to "read fluently, understand extended prose (both fiction and non-fiction) and be encouraged to read for pleasure." Schools should provide library facilities to encourage wider reading and set ambitious expectations for reading at home. In addition, reading at key stages 3 and 4 should be wide, varied and challenging. Pupils should be expected to read whole books, to read in depth and to read for pleasure and information. [10].

\subsubsection{The "Writing" Learning Area in the National Curriculum in England-English: Key Stage: 3}

The following explanations are given in the "writing" learning area section of the National Curriculum in England: "Pupils should continue to develop their knowledge of and skills in writing, refining their drafting skills and developing resilience to write at length. They should be taught to write formal and academic essays as well as writing imaginatively. They should be taught to write for a variety of purposes and audiences across a range of contexts. The writing they do should include narratives, explanations, descriptions, comparisons, summaries and evaluations: such writing supports them in rehearsing, understanding and consolidating what they have heard or read. Pupils should develop the stamina and skills to write at length, with accurate spelling and punctuation. They should be taught the correct use of grammar." [10].

\subsubsection{The "Grammar and Vocabulary" Learning Area in the National Curriculum in England-English: Key Stage: 3}

According to the explanations given in the "grammar and vocabulary" learning area section of the national curriculum; "through reading and writing activities, students' vocabulary should be developed. The teacher should show students how to understand that relationships between words and nuances in meaning and how to use figurative language. Students should be encouraged to check what they have told and written and why they have constructed their sentences as they are. Students should be tanght how to use age-appropriate vocabulary including linguistic and literary terminology. In this way, students will be able to discuss the language they have used while reading, writing and speaking and make it more effective" [10].

In the "grammar and vocabulary" learning area section, it is also stated that students' "vocabulary acquisition and knowledge are important for success in all the courses in the curriculum; therefore, teachers should build on the existing knowledge of students to develop their vocabulary. While doing this, they should encourage students to create links between the known words and new words and explain the differences between the meanings of similar words. Moreover, it is stated that students' knowing the meanings of all the words they encounter while reading in all the courses and introduction of the vocabulary specific to each course such as mathematics and science to students are of great importance" [10].

No explanations are made for the learning areas of "listening, speaking, reading and writing" in the Turkish Teaching Curriculum.

\subsection{Comparison of the National Curriculum in} England-English: Key Stage: 3 and Turkish Teaching Curriculum in terms of "Learning Outcomes"

The National Curriculum in England-English: Key Stage: 3 consists of "spoken language", "reading", "writing", "grammar and vocabulary" learning areas. In the curriculum, learning outcomes related to these four learning areas are addressed as a whole for key stage 3 .

The learning outcomes in the Turkish Teaching Curriculum are presented separately for each grade level from 1st grade to 8 th grade and for each of the learning areas (listening, speaking, reading, and writing). In the following table, the distribution of the learning outcomes for 6 th, 7 th and 8 th grades is given.

Table 6. The distribution of the learning outcomes in the Turkish Teaching Curriculum across the grades and learning areas

\begin{tabular}{|c|c|c|c|c|c|}
\hline & $\begin{array}{c}6^{\text {th }} \\
\text { Grade }\end{array}$ & $\begin{array}{c}7^{\text {th }} \\
\text { Grade }\end{array}$ & $\begin{array}{c}8^{\text {th }} \\
\text { Grade }\end{array}$ & Total & $\begin{array}{c}\text { Different } \\
\text { Learning } \\
\text { Outcomes }\end{array}$ \\
\hline Listening & 12 & 14 & 14 & 40 & $\mathbf{1 5}$ \\
\hline Speaking & 7 & 7 & 7 & 21 & $\mathbf{7}$ \\
\hline Reading & 35 & 38 & 35 & 108 & $\mathbf{4 2}$ \\
\hline Writing & 14 & 17 & 20 & 51 & $\mathbf{2 0}$ \\
\hline Total & 68 & 76 & 76 & 220 & $\mathbf{8 4}$ \\
\hline
\end{tabular}

In the Turkish Teaching Curriculum, there are a total of 220 learning outcomes for 6th, 7th and 8th grades; 40 for the listening learning area, 21 for the speaking learning area, 108 for the reading learning area and 51 for the writing learning area. Many of these learning outcomes are sometimes dealt with in three of the grade levels and sometimes two of the grade levels. 
As there is no grade level-based distinction between the learning outcomes in the National Curriculum in England-English: Key Stage: 3, the delivery of the learning outcomes in the two curriculums varies. Thus, it is not possible to compare the curriculums in terms of the learning outcomes according to grade level. Therefore, a general comparison was made for the middle school level. In order to properly compare the learning outcomes in the two curriculums, the learning outcomes stated in the Turkish Teaching Curriculum were combined. To this end, the learning outcomes repeated in the curriculum were determined and written as a single learning outcome and in this way, the learning outcomes of the three grades were determined for all the learning areas. In Table 6, the numbers given in the "different learning outcomes" column refer to the numbers of learning outcomes calculated by writing the repeated learning outcomes once. In this way, a total of 15 learning outcomes were found for the listening learning area in 6th, 7th and 8th grades of the Turkish Teaching Curriculum, 7 for the speaking learning area, 42 for the reading learning area and 21 for the writing learning area; a total of 84 different learning outcomes.

Comparisons of the learning outcomes are first presented for the learning areas of "reading", "writing", "speaking", which are common in both of the curriculums and then the learning outcomes for "grammar and vocabulary" learning area and "listening" learning area are presented.

\subsection{1. "Reading" Learning Outcomes in the National Curriculum in England-English: Key Stage: 3 and Turkish Teaching} Curriculum

Table 7. Learning Outcomes of the "Reading" Learning Area in the National Curriculum in England-English: Key Stage: 3

\begin{tabular}{|c|c|}
\hline \multicolumn{2}{|c|}{ Learning Outcomes of the Reading Learning Area } \\
\hline \multirow{3}{*}{$\begin{array}{l}\text { Develop an appreciation and } \\
\text { love of reading, and read } \\
\text { increasingly challenging } \\
\text { material independently } \\
\text { through: }\end{array}$} & $\begin{array}{l}\text { reading a wide range of fiction and non-fiction, including in particular whole books, short stories, poems } \\
\text { and plays with a wide coverage of genres, historical periods, forms and authors. The range will include } \\
\text { high-quality works from: } \\
\text { - } \quad \text { English literature, both pre-1914 and contemporary, including prose, poetry and drama } \\
\text { - } \quad \text { Shakespeare (two plays) } \\
\text { - } \quad \text { seminal world literature }\end{array}$ \\
\hline & choosing and reading books independently for challenge, interest and enjoyment. \\
\hline & $\begin{array}{l}\text { re-reading books encountered earlier to increase familiarity with them and provide a basis for making } \\
\text { comparisons. }\end{array}$ \\
\hline \multirow{4}{*}{$\begin{array}{l}\text { Understand increasingly } \\
\text { challenging texts through: }\end{array}$} & $\begin{array}{l}\text { learning new vocabulary, relating it explicitly to known vocabulary and understanding it with the help of } \\
\text { context and dictionaries }\end{array}$ \\
\hline & making inferences and referring to evidence in the text \\
\hline & $\begin{array}{l}\text { knowing the purpose, audience for and context of the writing and drawing on this knowledge to support } \\
\text { comprehension }\end{array}$ \\
\hline & checking their understanding to make sure that what they have read makes sense. \\
\hline \multirow{6}{*}{ Read critically through: } & $\begin{array}{l}\text { knowing how language, including figurative language, vocabulary choice, grammar, text structure and } \\
\text { organisational features, presents meaning }\end{array}$ \\
\hline & recognising a range of poetic conventions and understanding how these have been used \\
\hline & studying setting, plot, and characterisation, and the effects of these \\
\hline & $\begin{array}{l}\text { understanding how the work of dramatists is communicated effectively through performance and how } \\
\text { alternative staging allows for different interpretations of a play }\end{array}$ \\
\hline & making critical comparisons across texts \\
\hline & at least two authors in deptn each year. \\
\hline
\end{tabular}

Learning outcomes related to the "reading" learning area in the National Curriculum in England English: Key Stage: 3 are subsumed under three headings which are "to develop an appreciation and love of reading", "to read increasingly challenging material independently", "to understand increasingly challenging texts and to read critically". The curriculum directly points to the national literary works to develop an appreciation and love of reading and to read increasingly challenging texts. These literary works include both pre-1914 and contemporary literary works, plays of Shakespeare and seminal works of world literature. While the learning outcomes of the reading learning area are explained in the curriculum, through the word "challenging" used in the sentences "reading increasingly challenging material independently" and "understanding increasingly challenging texts", the desire to make students continuously confronted with increasingly challenging literary works is indicated. Again the learning outcome expressed with the sentence "choosing and reading books independently for challenge, interest and enjoyment" indicates the desire to inculcate "reading culture" in students. The learning outcome expressed with this sentence "re-reading books encountered earlier" aims to show students that they can establish new connections in each reading and can derive new meanings and messages in light of the information gained previously. 
Table 8. Learning Outcomes of the "Reading" Learning Area in the Turkish Teaching Curriculum

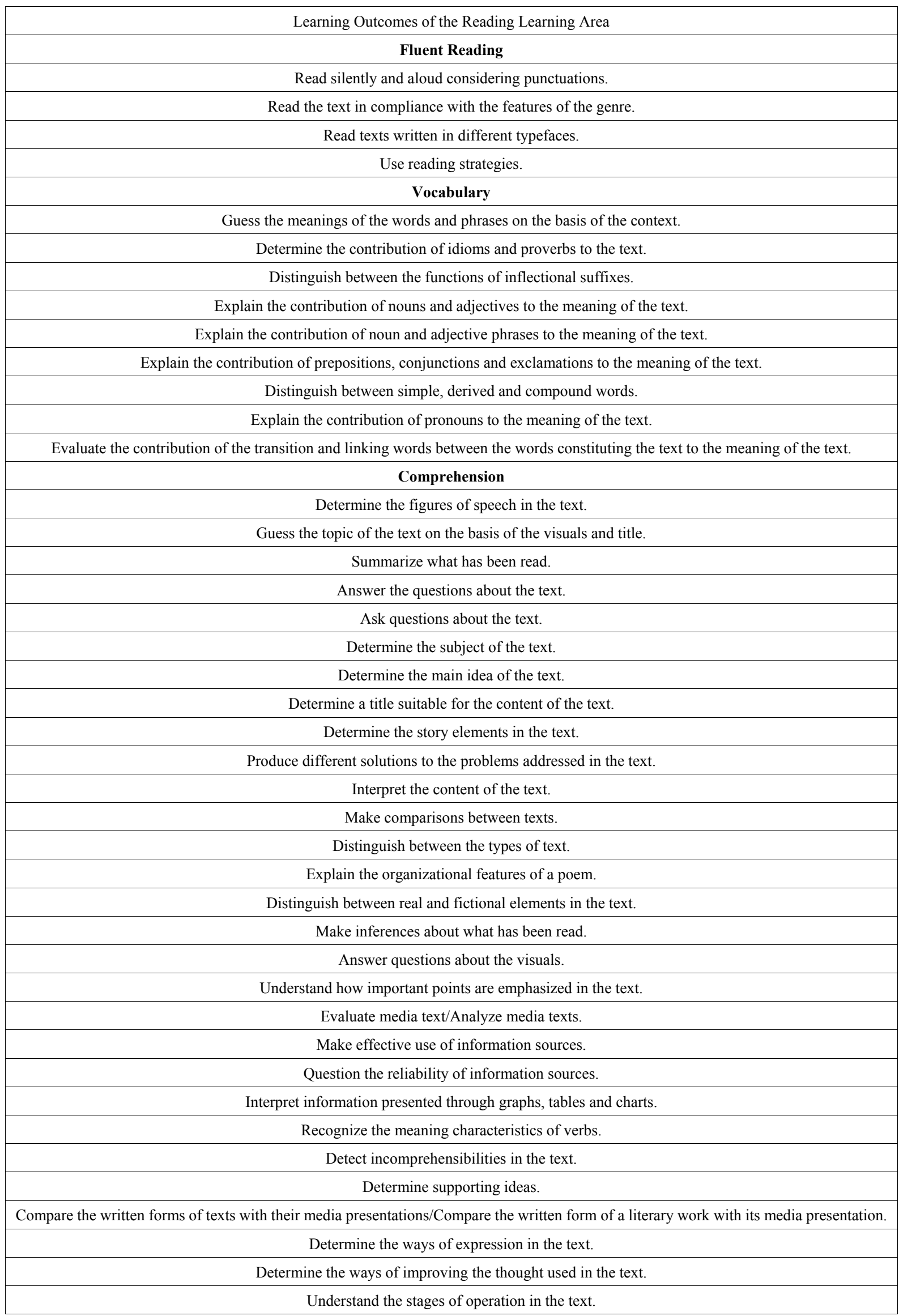


In the Turkish Teaching Curriculum, the learning outcomes of the "reading" learning area are dealt with under three sub-headings which are "fluent reading", "vocabulary" and "comprehension". In the "fluent reading" section of the "reading" learning area, there are four learning outcomes which are reading silently and aloud, using reading strategies, reading texts in compliance with the features of the genre and reading texts written in different typefaces.

Two of the nine learning outcomes stated in the "vocabulary" section of the "reading" learning area are directly related to the development of vocabulary, seven of them are related to the "grammar" learning area. The learning outcomes related to vocabulary are learning new words on the basis of the context and learning idioms and proverbs and the learning outcomes related to grammar are learning inflectional suffixes, nouns, adjectives, pronouns, prepositions, conjunctions, exclamations, noun and adjective phrases, simple, derived and compound words.

Of the 29 learning outcomes found in the "comprehension" section of this learning area, two that are related to "meaning characteristics of verbs" are directly connected with the learning area of grammar. The other learning outcomes ranging from guessing the title of the text to interpreting the visuals, from determining the story elements to interpreting the content of the text refer to all the learning outcomes helping to understand a text built on an event, information or emotions. In this section, there are also some learning outcomes related to literature as literary texts are used as the main tools in Turkish classes.

The national curriculum in England puts great emphasis on the selection of the materials and selection of these materials from the national literature for the "reading" learning area. Moreover, the national curriculum brings learning outcomes regarding reading book for pleasure and analyzing writers to the fore. In addition, in the "reading" learning area, importance is attached to some other learning outcomes such as re-reading a previously read book and recognizing that a play can be interpreted in different ways. Though the learning outcomes related to the comprehension of a text exhibit some similarities in the curriculums of the two countries, in the Turkish Teaching Curriculum, stages involved in the understanding of a text are given in a much more detailed manner.

3.4.2. "Writing" Learning Outcomes in the National Curriculum in England-English: Key Stage: 3 and Turkish Teaching Curriculum

Table 9. Learning Outcomes of the "Writing" Learning Area in the National Curriculum in England-English: Key Stage: 3

\begin{tabular}{|c|c|}
\hline & Learning Outcomes of the Writing Learning Area \\
\hline \multirow{4}{*}{$\begin{array}{l}\text { Write accurately, fluently, } \\
\text { effectively and at length for } \\
\text { pleasure and information } \\
\text { through: }\end{array}$} & $\begin{array}{l}\text { writing for a wide range of purposes and audiences, including: } \\
\text { - } \quad \text { well-structured formal expository and narrative essays } \\
\text { - } \quad \text { stories, scripts, poetry and other imaginative writing } \\
\text { - } \quad \text { notes and polished scripts for talks and presentations } \\
\text { a range of other narrative and non-narrative texts, including arguments, and personal and } \\
\text { formal letters }\end{array}$ \\
\hline & $\begin{array}{l}\text { summarising and organising material, and supporting ideas and arguments with any necessary factual } \\
\text { detail }\end{array}$ \\
\hline & $\begin{array}{l}\text { applying their growing knowledge of vocabulary, grammar and text structure to their writing and } \\
\text { selecting the appropriate form }\end{array}$ \\
\hline & $\begin{array}{l}\text { drawing on knowledge of literary and rhetorical devices from their reading and listening to enhance the } \\
\text { impact of their writing }\end{array}$ \\
\hline \multirow{3}{*}{$\begin{array}{l}\text { Plan, draft, edit and proof-read } \\
\text { through: }\end{array}$} & considering how their writing reflects the audiences and purposes for which it was intended \\
\hline & $\begin{array}{l}\text { amending the vocabulary, grammar and structure of their writing to improve its coherence and overall } \\
\text { effectiveness }\end{array}$ \\
\hline & $\begin{array}{l}\text { paying attention to accurate grammar, punctuation and spelling; applying the spelling patterns and rules } \\
\text { set out in English Appendix } 1 \text { to the key stage } 1 \text { and } 2 \text { programmes of study for English. }\end{array}$ \\
\hline
\end{tabular}

In the National Curriculum in England-English: Key Stage: 3, the abundance of writing genres addressed is remarkable. Here, students are expected to write for a wide range of purposes and audiences such as stories, scenarios and poems, informative and expository essays, scripts, notes, polished scripts for talks, official and private letters. Here the learning outcomes such as creating the draft, determining the purpose and target audience and amending the vocabulary, grammar and structure of their writing etc. are connected with the stages of process-based writing 
Table 10. Learning Outcomes of the "Writing" Learning Area in the Turkish Teaching Curriculum

\begin{tabular}{|c|c|}
\hline \multicolumn{2}{|c|}{ Learning Outcomes of the "Writing" Learning Area } \\
\hline Write poems. & Share their writings. \\
\hline Write informative essays. & $\begin{array}{c}\text { Use the Turkish versions of the } \\
\text { words directly borrowed from } \\
\text { foreign languages. }\end{array}$ \\
\hline Write expository essays. & $\begin{array}{c}\text { Fill in the forms in line with } \\
\text { instructions. }\end{array}$ \\
\hline Apply writing strategies. & Write short texts. \\
\hline $\begin{array}{c}\text { Use graphs and tables when } \\
\text { needed to support their } \\
\text { writings./Use graphs and } \\
\text { tables to support narration. }\end{array}$ & $\begin{array}{c}\text { Exploit different narrative styles } \\
\text { in their writings. }\end{array}$ \\
\hline $\begin{array}{c}\text { Write a task according to } \\
\text { certain stages. }\end{array}$ & $\begin{array}{c}\text { Use auxiliary verbs in line with } \\
\text { their functions. }\end{array}$ \\
\hline $\begin{array}{c}\text { Use idioms, proverbs sayings } \\
\text { to enhance their writings. }\end{array}$ & $\begin{array}{c}\text { Present the results of their } \\
\text { research in writing. }\end{array}$ \\
\hline $\begin{array}{c}\text { Set the title appropriate for } \\
\text { their writing. }\end{array}$ & $\begin{array}{c}\text { Identify the elements of a } \\
\text { sentence. }\end{array}$ \\
\hline $\begin{array}{c}\text { Use transitions and linking } \\
\text { words appropriate for their } \\
\text { writings. }\end{array}$ & $\begin{array}{c}\text { Recognize different sentence } \\
\text { types. }\end{array}$ \\
\hline Revise their writings. & $\begin{array}{c}\text { Understand the contribution of the } \\
\text { forms of verbs to the meaning. }\end{array}$ \\
\hline
\end{tabular}

Of the 20 learning outcomes found in the "writing" learning area of the Turkish Teaching Curriculum, one is related to writing strategies, two are related to vocabulary, five are related to grammar and the remaining 12 are directly related to the "writing" area. Here, students are expected to write texts ranging from poems to informative and expository texts; to enhance their writings with visuals, to find suitable titles for their writings, to present their research findings in writing and to design and share their writings.

When the two curriculums are compared in terms the "writing" learning area, it is seen that in the National Curriculum in England, emphasis is put on doing writing in a wide range of genres. In the Turkish Teaching Curriculum, writing in wide range of genres is not mentioned. Instead, the types of texts to be presented in textbooks across the grade levels are explained for textbook writers and publishers [9].

\subsubsection{Learning Outcomes of the "Spoken Language" Learning Area in the National Curriculum in England-English: Key Stage: 3 and the Turkish Teaching Curriculum}

In relation to the "spoken language" learning area, the National Curriculum in England expects students to participate in discussions, to express their opinions keeping to the point, to summarize and build on what has been said, to give short speeches and presentations, to perform play scripts and poetry and while doing this, to pay attention to intonation and tone and to use Standard English confidently.

In the Turkish Teaching Curriculum, there are seven learning outcomes in the "speaking" learning area. One of them is related to speaking strategies, one of them is related to grammar and two of them are related to vocabulary. The remaining three are related to giving prepared and unprepared speeches, using body language effectively while doing this. When the curriculums of the two countries are compared in this regard, it is seen that in the Turkish.

Table 11. Learning Outcomes of the "Spoken Language" Learning Area in the National Curriculum in England-English: Key Stage: 3

\begin{tabular}{|c|c|}
\hline \multicolumn{2}{|c|}{ Learning Outcomes of the Spoken Language Learning Area } \\
\hline \multirow{4}{*}{$\begin{array}{c}\text { Speak } \\
\text { confidently and } \\
\text { effectively, } \\
\text { including } \\
\text { through: }\end{array}$} & $\begin{array}{c}\text { using Standard English confidently in a range } \\
\text { of formal and informal contexts, including } \\
\text { classroom discussion }\end{array}$ \\
\cline { 2 - 3 } & $\begin{array}{c}\text { giving short speeches and presentations, } \\
\text { expressing their own ideas and keeping to the } \\
\text { point }\end{array}$ \\
\cline { 2 - 2 } & $\begin{array}{c}\text { participating in formal debates and structured } \\
\text { discussions, summarising and/or building on } \\
\text { what has been said }\end{array}$ \\
\cline { 2 - 3 } & $\begin{array}{c}\text { improvising, rehearsing and performing play } \\
\text { scripts and poetry in order to generate language } \\
\text { and discuss language use and meaning, using } \\
\text { role, intonation, tone, volume, mood, silence, } \\
\text { stillness and action to add impact. }\end{array}$ \\
\hline
\end{tabular}

Table 12. Learning Outcomes of the "Speaking" Learning Area in the Turkish Teaching Curriculum

\begin{tabular}{|c|c|}
\hline \multicolumn{2}{|c|}{ Learning Outcomes of the Speaking Learning Area } \\
\hline Give prepared speeches. & $\begin{array}{c}\text { Use words properly to reflect their } \\
\text { correct meanings. }\end{array}$ \\
\hline $\begin{array}{c}\text { Give unprepared } \\
\text { speeches. }\end{array}$ & $\begin{array}{c}\text { Use appropriate transition and linking } \\
\text { words in their speeches. }\end{array}$ \\
\hline Use speaking strategies. & $\begin{array}{c}\text { Use the Turkish versions of the words } \\
\text { directly borrowed from foreign } \\
\text { languages. }\end{array}$ \\
\hline $\begin{array}{c}\text { Use body language } \\
\text { effectively while } \\
\text { speaking. }\end{array}$ & \\
\hline
\end{tabular}

Teaching Curriculum the learning outcomes concerning the speaking learning area are expressed in general, while in the National Curriculum in England, more detail is given.

\subsubsection{Learning Outcomes of the "Grammar and Vocabulary" in the National Curriculum in England-English: Key Stage: 3 and the Turkish Teaching Curriculum}

In the National Curriculum in England-English: Key Stage: 3 [10], in relation to the teaching of grammar and vocabulary, there are learning outcomes directly related to grammar such as using the grammar rules they have learned in key stages 1 and 2, using the vocabulary and grammar structures they have learned through reading and listening in speaking and writing, and analyzing the linguistic features of texts. The learning outcomes related to vocabulary are students' knowing the differences between the Standard English and other varieties of English, understanding and speaking Standard English and confidently using it in their writings and precisely and confidently using literary terminology. 
Table 13. Learning Outcomes of the "Grammar and Vocabulary" Learning Area in the National Curriculum in England-English: Key Stage: 3

\begin{tabular}{|c|c|}
\hline \multicolumn{2}{|c|}{ Learning Outcomes of the Grammar and Vocabulary Learning Area } \\
\hline \multirow{6}{*}{$\begin{array}{l}\text { Consolidate and } \\
\text { build on their } \\
\text { knowledge of } \\
\text { grammar and } \\
\text { vocabulary } \\
\text { through: }\end{array}$} & $\begin{array}{l}\text { extending and applying the grammatical } \\
\text { knowledge set out in English Appendix } 2 \text { to the } \\
\text { key stage } 1 \text { and } 2 \text { programmes of study to } \\
\text { analyse more challenging texts }\end{array}$ \\
\hline & $\begin{array}{l}\text { studying the effectiveness and impact of the } \\
\text { grammatical features of the texts they read }\end{array}$ \\
\hline & $\begin{array}{l}\text { drawing on new vocabulary and grammatical } \\
\text { constructions from their reading and listening, } \\
\text { and using these consciously in their writing and } \\
\text { speech to achieve particular effects }\end{array}$ \\
\hline & $\begin{array}{l}\text { knowing and understanding the differences } \\
\text { between spoken and written language, including } \\
\text { differences associated with formal and informal } \\
\text { registers, and between Standard English and } \\
\text { other varieties of English }\end{array}$ \\
\hline & $\begin{array}{l}\text { using Standard English confidently in their own } \\
\text { writing and speech }\end{array}$ \\
\hline & $\begin{array}{c}\text { discussing reading, writing and spoken } \\
\text { language with precise and confident use of } \\
\text { linguistic and literary terminology }\end{array}$ \\
\hline
\end{tabular}

In the Turkish Teaching Curriculum [9], learning outcomes concerning grammar are not given in a separate section, rather incorporated into the learning areas of speaking, reading (vocabulary and comprehension) and writing. In the curriculum, the learning outcomes related to grammar are using suitable transition and linking words in their speeches and writings, understanding inflectional suffixes and word structures, understanding nouns, adjectives, prepositions, exclamations, pronouns, verbs and auxiliary verbs and recognizing sentence types and elements of a sentence.

In the Turkish Teaching Curriculum [9], the learning outcomes related to vocabulary are given under a sub-heading within the reading learning area. Yet, some of the learning outcomes presented here are learning outcomes of grammar. In addition, some learning outcomes related to vocabulary are found in the learning areas of listening, speaking and writing. In the curriculum, the learning outcomes related to vocabulary are "guessing the meaning of words from the context, understanding and using idioms and proverbs and using the Turkish versions of the words borrowed from foreign languages".

When the curriculums of the two countries are compared in terms of grammar and vocabulary, it is seen that both of them aim to teach the grammar rules of their own languages and to enable students to use these rules and to teach new words for students to use them in their speeches and writings. In this regard, there are some similarities between the two curriculums.

\subsubsection{Learning Outcomes of the "Listening" Learning} Area in the National Curriculum in England-English: Key Stage: 3 and Turkish Teaching Curriculum

In the Turkish Teaching Curriculum [9], it is stated that "8 themes will be used at all the grade levels and in each theme 4 texts will be used; 3 of these texts will be for reading and one of them will be for listening/watching" [9]. In this way, the learning outcomes related to the "listening" learning area are given separately in the curriculum. One of the 15 learning outcomes found in this section (Guess the meaning of the words they do not know in what they have listened/watched.) is directly related to the vocabulary learning area, one of them is related to listening strategies and the remaining 13 learning outcomes are related to understanding what has been listened. These 13 learning outcomes involve guessing the end of the text they have listened, determining the topic of the text, answering questions about the text and determining the main idea/emotion of the text. In addition to this, there are some other learning outcomes demanding higher order thinking skills such as suggesting a new title for a text, recognizing the implicit messages in the text and evaluating the content of the text.

Table 14. Learning Outcomes of the "Listening" Learning Area in the Turkish Teaching Curriculum

\begin{tabular}{|c|c|}
\hline \multicolumn{2}{|c|}{ Learning Outcomes of the Listening Learning Area } \\
\hline $\begin{array}{l}\text { Understand the incidences } \\
\text { occurring in what they } \\
\text { listen/watch and make guesses } \\
\text { about their progress and result. }\end{array}$ & $\begin{array}{c}\text { Recognize non-verbal messages } \\
\text { of the speaker. }\end{array}$ \\
\hline $\begin{array}{l}\text { Guess the meaning of the words } \\
\text { they do not know in what they } \\
\text { have listened/watched. }\end{array}$ & $\begin{array}{l}\text { Evaluate the content of what } \\
\text { they have listened/watched. }\end{array}$ \\
\hline $\begin{array}{l}\text { Summaries what they have } \\
\text { listened/watched. }\end{array}$ & $\begin{array}{c}\text { Express their opinions about } \\
\text { what they have } \\
\text { listened/watched. }\end{array}$ \\
\hline $\begin{array}{l}\text { Answer questions about what } \\
\text { they have listened/watched. }\end{array}$ & Apply listening strategies. \\
\hline $\begin{array}{l}\text { Determine the topic of what } \\
\text { they have listened/watched. }\end{array}$ & $\begin{array}{l}\text { Determine the ways of } \\
\text { improving thinking used in } \\
\text { what they have } \\
\text { listened/watched. }\end{array}$ \\
\hline $\begin{array}{l}\text { Determine the main idea/feeling } \\
\text { of what they have } \\
\text { listened/watched. }\end{array}$ & $\begin{array}{c}\text { Question the consistency in } \\
\text { what they have } \\
\text { listened/watched. }\end{array}$ \\
\hline $\begin{array}{l}\text { Suggest different titles for what } \\
\text { they have listened/watched. }\end{array}$ & $\begin{array}{l}\text { Evaluate media text they have } \\
\text { listened/watched. }\end{array}$ \\
\hline $\begin{array}{l}\text { Act out narrative texts they have } \\
\text { listened/watched. }\end{array}$ & \\
\hline
\end{tabular}

In the National Curriculum in England, there is no separate section allocated to the listening learning area. Only in the learning areas of "writing" and "grammar and vocabulary" listening skill is addressed with these statements "drawing on knowledge of literary and rhetorical devices from their reading and listening to enhance the impact of their writing" and "drawing on new vocabulary and grammatical constructions from their reading and listening... [10]". When the curriculums of the two countries are examined, it is seen that the learning outcomes in the "listening" learning area are more in the Turkish Teaching Curriculum.

\section{Conclusions}

In the current study conducted to compare the mother 
tongue teaching curriculums implemented at the middle school level in Turkey and England to reveal their similarities and differences, the Turkish Teaching Curriculum and the National Curriculum in England-English: Key Stage: 3 were analyzed. The curriculums of the two countries were compared in terms of "structure, objectives, learning areas and learning outcomes".

In England, 12-year compulsory education covering children aged at 5-16 is divided into four periods (key stages). The first two-year period of the compulsory education is called key stage 1, the following four-year period is called key stage 2, the next three-year period is called key stage 3 and the last two-year period is called key stage 4 [12]. In the Turkey; on the other hand, 12-year compulsory education is divided into three periods. The first four-year period covers the elementary education, the second four-year period covers the middle school education and the last four-year period covers the high school education. Thus, Key Stage 3 covers students aged 11-14 and corresponds to 6th, 7th and 8th grades of the Turkish middle school education.

The national curriculum in England is developed on the basis of periods and the contents and courses to be thought are developed for the period. While developing curriculums in Turkey, they are prepared on the basis of grade levels. While the elementary and middle school curriculums are developed together, the high school curriculum is developed separately. In the curriculum developed for the first eight-year compulsory education is built on courses and the content of each course from 1st grade to 8 th grade is given in detail.

Though the 12-year compulsory education is divided into certain periods, the number of these periods and their division are different in the two countries. Here the main difference stems from the existence of two curriculums in England which are the "national curriculum" and the" school curriculum". The national curriculum is the core curriculum to be compulsorily followed by all community and foundation schools, including private schools. While the national curriculum presents the main objectives to be accomplished by students, the details are left to schools. In addition to this, each school has its own curriculum comprising all learning and other experiences that each school plans for its pupils. As long as they teach the content of the national curriculum programmes to their all students, schools are free to decide how to organize the instructional process [10]. All the schools in England are obliged to publish their own special curriculums online by indicating the courses and academic year. On the other hand, schools are free to plan their own instructional programmes and to add the courses and subjects they want to their curriculums. In Turkey however there is a single curriculum issued by the Ministry of National Education. All schools have to abide by this curriculum, no addition to or subtraction from the curriculum is allowed. The structure in England allows students to develop their own curriculums and to determine course contents. As long as teachers enable students to accomplish the objectives stated in the national curriculum, they have considerable freedom to choose the subjects they will teach, the books and supplementary materials they will use. Thus, the curriculum has a flexible structure. Therefore, mother tongue teachers in England can play more important roles than mother tongue teachers in Turkey.

When the curriculums are examined in terms of objectives, it is seen that great emphasis is put on the effective use of language skills, development of vocabulary and teaching of grammar rules. In the National Curriculum in England-English: Key Stage: 3, special importance is attached to speaking, discussion and presentation skills. Another point remarkable in the National Curriculum in England-English: Key Stage: 3 is the emphasis put on teaching the works of English literature. This importance is expressed in the curriculum with the following sentence [10] "appreciate our rich and varied literary heritage". The works of English literature are defined as heritage in the curriculum and this heritage is defined with the words rich and varied; all these indicate that the programs aims to promote students to appreciate the English literature. The statement explaining an objective in the curriculum [10] "develop the habit of reading widely and often, for both pleasure and information" indicates that what is aimed is not only to make students acquire reading as a skill but also to make them read for pleasure and turn reading into a habit. This objective is of great importance as reading is the primary means of mental, social and cultural development of the individual. Different from the National Curriculum in England, the Turkish Teaching Curriculum [9] aims to impart national, spiritual, cultural and social values to students and enable them to cognitively question, interpret and construct information.

When the curriculums are evaluated in terms of learning areas, it is seen that there are short explanations for the learning areas of "reading", "writing", "spoken language" and "grammar" in the National Curriculum in England-English: Key Stage: 3. Though there are four learning areas in the Turkish Teaching Curriculum which are "listening", "speaking", "reading" and "writing", there is no explanation about these learning areas.

The comparison of the curriculums in terms learning outcomes is first presented for the learning areas of "reading", "writing", "speaking" and then for the learning areas of "grammar and vocabulary" and "listening".

When the learning outcomes related to the learning area of "reading" are examined, it is seen that great emphasis is put on the selection of the materials to be used for reading and on the selection of these materials from among the works of national literature. In addition to the learning outcomes related to the processing of a text, there are some other learning outcomes demanding students to read for pleasure and to analyze writers. The learning outcome in 
the learning area of reading "re-reading the books encountered earlier" aims to show students that they can establish new connections in each reading and can derive new meanings and messages in light of the information gained previously. In this regard, Özdemir [13] states in relation to the Don Quixote by Cervantes "Every man must read Don Quixote three times in his/her life. Once in adolescence when laughs easily activate feelings; then again in the middle ages when reasoning starts to dominate and finally in the old ages when the person sees everything from a philosophical point of view. "In every period of life, new information and experiences are gained and when a book is re-read in light of this new information and these new experiences, new meaning can be derived and new tastes can be taken from a previously read book. In the curriculum, there are also some learning outcomes aiming to raise students' awareness of the fact that a play can be interpreted differently in each staging. The learning outcome stated in the National Curriculum in England "choosing and reading books independently for challenge, interest and enjoyment" is directly connected with the reading culture. The reading culture is "the culture of the individuals who have been introduced to the world of works of written culture; have developed the competence needed to share, test and question the messages presented to them by this world; and have been accustomed to living with the opportunities presented by them" [14]. In this regard, the learning outcomes stated in the learning area of "reading" in the Turkish Teaching Curriculum should be enhanced. On the other hand, while the learning outcomes regarding the comprehension of a text exhibit some similarities, the learning outcomes related to the comprehension of a text are presented in a more detailed manner in the Turkish Teaching Curriculum.

In relation to the learning area of "writing", in the National Curriculum in England, emphasis is put on doing writing in a wide range of genres. Such activities are believed to contribute to the development of students' writing skills. In the writing learning area of the Turkish Teaching Curriculum, writing in a wide range of genres is not mentioned. Though the types of texts to be included at each grade level are given in the curriculum, the types of writing activities to be conducted on these types of texts are not given; this information should be given in the writing skill section.

When the curriculums are evaluated in terms of the spoken learning area, it is seen that the number of learning outcomes directly given for the speaking skill in the Turkish Teaching Curriculum is inadequate; in contrast, there are many learning outcomes concerning the speaking skill in the National Curriculum in England. The speaking learning area in the Turkish Teaching Curriculum can be enhanced through learning outcomes related to discussion, expressing one's own idea and using Turkish properly.

The learning area of "grammar and vocabulary" addressed as a separate section in the National Curriculum in England demands students to learn the rules of the language, to use these rules in their speeches and writings, to learn new words and to use them. In this regard, the Turkish Teaching Curriculum seems to have similar learning outcomes related to grammar and vocabulary teaching; thus, the two curriculums have common learning outcomes in relation to grammar and vocabulary teaching. While the learning outcomes of the grammar learning area are not given under a separate heading in the Turkish Teaching Curriculum, the learning outcomes of the vocabulary learning area are given under a sub-heading within the learning area of "reading".

The learning area of "listening" given under a separate heading in the Turkish Teaching curriculum and highly detailed learning outcomes are given regarding this learning area. Here there are learning outcomes such as recognizing the implicit messages in a text and evaluating the content of a text as well as understanding a listening text and determining the main idea of a text. In the National Curriculum in England, "listening" is not addressed as a separate learning area rather is given within the learning areas of "writing" and "grammar and vocabulary" as follows "drawing on knowledge of literary and rhetorical devices from their reading and listening to enhance the impact of their writing" and "drawing on new vocabulary and grammatical constructions from their reading and listening... [12]". When the two curriculums are examined in terms of the learning area of "listening", it is seen that there are many more learning outcomes related to listening in the Turkish Teaching Curriculum.

Continuously renewing, developing and improving the curriculums are one of the most important things that a country should do about education. To this end, many comparative and critical studies have been conducted on curriculums. As on the Turkish Teaching Curriculum, many studies have been carried out on the National Curriculum in England. Oates [15] did a study to enhance the National Curriculum in England and revealed the benefits and ills of the curriculum. In their project intended to help children for a smooth transition from elementary education to secondary education, Evangelou et al. [16] stated that unnecessary content reiteration in the National Curriculum in England was reduced.

Research on education systems may help countries see the weaknesses and strengths of their own education systems and thus make changes. Comparative educational research is an important area of research for countries to get to know their education systems better on the basis of comparisons [17]. In this way, countries can see the weaknesses and strengths of their own curriculums. A good curriculum directly affects the quality of the instruction to be delivered. Curriculums should be continuously revised considering both needs and scientific development. In this regard, by analyzing the curriculums of different countries, best practices can be adopted and thus curriculums can be improved. In this connection, when the National 
Curriculum in England and the Turkish Teaching Curriculum are compared, it is seen that more works of Turkish literature should be added to the Turkish Teaching Curriculum. To the reading skill section of the curriculum, new learning outcomes aiming to develop reading culture and to enable students to choose books they want to read can be added and to the writing learning area of the curriculum, learning outcomes related to writing in wide range of genres can be added. Moreover, the speaking learning area can be enhanced through the addition of learning outcomes such as making oral presentations, discussing, expressing one's own ideas and using Turkish properly to the Turkish Teaching Curriculum.

\section{REFERENCES}

[1] D. Aksan. Her Yönüyle Dil Ana Çizgileriyle Dilbilim, Türk Dil Kurumu, Ankara, 2003.

[2] D. Aksan. Anadili, Dilbilim ve Türkçe Yazıları, Multilingual,.İstanbul, 2004.

[3] S. Sever, Z. Kaya, C. Aslan, Etkinliklerle Türkçe Öğretimi, Morpa, İstanbul, 2008.

[4] F. Varış. Eğitimde Program Geliştirme "Teori ve Teknikler”, Ankara Üniversitesi Basımevi, Ankara, 1988.

[5] J. A. Lauwerys, F. Varış, K. Neff. Mukayeseli Eğitim. Ankara Üniversitesi Eğitim Fakültesi Yayınları, No.13, Ankara, 1971.

[6] A. Türkoğlu. Karşılaştırmalı Eğitim Dünya Ülkelerinden Örneklerle. Baki, Adana, 1998.

[7] N. Karasar. Bilimsel Araştırma Yöntemi, Nobel, Ankara, 1999.

[8] A. Yıldırım, H. Şimşek. Sosyal Bilimlerde Nitel Araştırma
Yöntemleri. Seçkin, Ankara, 2005.

[9] Türkçe Dersi Öğretim Programı (İlkokul ve Ortaokul 1, 2, 3, 4, 5, 6, 7 ve 8. Sınıflar), Milli Eğitim Bakanlığı, Ankara, 2018, Online available from http://mufredat.meb.gov.tr/Do syalar/201812312239736-T\%C3\%BCrk\%C3\%A7e\%20\% C3\%96\%C4\%9Fretim\%20Program\%C4\%B1\%202018.pdf

[10] The National Curriculum in England-Key Stages 3 and 4 Framework Document Department for Education, 2014, Online available from https:/www.gov.uk/government/upl oads/system/uploads/attachment_data/file/381754/SECON DARY_national_curriculum.pdf

[11] 12 Y1llık Zorunlu Eğitime Yönelik Genelge, Online available from http://www.meb.gov.tr/haberler/2012/12Yil likZorunluEgitimeYonelikGenelge.pdf

[12] The National Curriculum, Online available from https://www.gov.uk/national-curriculum

[13] E. Özdemir. Türk ve Dünya Edebiyatında Dönemler-Yönelimler. Bilgi, Ankara, 1999.

[14] S. Sever. Okuma Kültürü Edinme Sürecinde Türkçe Öğretiminin Sorumluluğu, Okuma Kültürü ve Okullarda Uygulama Sorunları Toplantısı, Milli Eğitim Bakanlığı, Ankara, 108-126, 2007.

[15] T. Oates. Could do better: using international comparisons to refine the National Curriculum in England. Curriculum Journal, Vol.22, No.2, 121-150, 2011.

[16] M. Evangelou, B. Taggart, K. Sylva, E. Melhuish, P. Sammons, I. Siraj-Blatchford. Effective Pre-school, Primary and Secondary Education 3-14 Project (EPPSE 314): What makes a successful transition from primary to secondary school? DCSF Research Report, DCSF-RR019. London: Institute of Education, University of London/Department for Children, Schools and Families, 2008.

[17] G. Göçen Kabaran, İ. Görgen. Güney Kore, Hong Kong, Singapur ve Türkiye'deki öğretmen yetiştirme sistemlerinin karşılaştırmalı olarak incelenmesi. Bartın Üniversitesi Eğitim Fakültesi Dergisi, Vol.10, No.5, 478-495, 2016. 